\title{
Quest for Identity in the novels of Beloved and The Bluest Eye by Toni Morrison
}

\author{
Nehdeep Lakra ${ }^{a}$, V.M. Berlin Grace ${ }^{\mathrm{b}}$ and D. David Wilson ${ }^{\mathrm{c} *}$ \\ A*Deparment of English, Karunya Institute of Technology and Sciences, Coimbatore-641 114, Tamil Nadu, S.India \\ bepartment of English, Karunya Institute of Technology and Sciences, Coimbatore-641 114, Tamil Nadu, S. India \\ 'Department of Biotechnology, Karunya Institute of Technology and Sciences, Coimbatore-641 114, Tamil Nadu, S. India \\ 1* is corresponding Author
}

Article History: Received: 11 January 2021; Accepted: 27 February 2021; Published online: 5 April 2021

\begin{abstract}
Identity is often described as finite and consists of separate and distinct parts such as; family, culture, personal relations and profession, to name a few. The formation of identity is an ever - evolving one wherein our genealogy, culture, loved ones, those we cared for, people who have harmed us and people we have harmed, our memories of the various phases of life, or the deeds done to oneself and to others, experiences lived and choices made, all come together to form who one is, at a given moment. The black Americans in the select novels are neglected even not to be considered as human beings, deprived of their rights. This article deals with the search for self as to who they truly are in the novel of Toni Morrison's Beloved and The Bluest Eye. Identity is the uniqueness of a person and when it is lost, the person loses everything in his life.
\end{abstract}

Keywords: Black, self -identity, family, slavery, quest.

\section{Introduction}

Toni Morrison's novels address issues such as racial tension, sexism and lustful desires, apart from the many individual themes that apply to specific novels. The underlying themes in almost all of Morrisons's novels are; the effects of slavery, the rootlessness of the Black minority and their crises of identity both as Black citizens, and as freed slaves. In her novel, The Bluest Eye, Morrison has depicted the dilemma of a Black, young girl who searches for her true identity and is frustrated by her blackness she yearns for love and acceptance, and a white complexion. In Beloved, the inhuman treatment of slaves and its consequent impact on their psyche has been depicted, through the characters. The similarity between the two novels, however, is the struggle to create an identity that each of the characters has to go through. In both these novels, Morrison has depicted the arduous that these characters embark upon, in order to make a place for themselves, in society - in order to be accepted as individual entities.

Identity is a socially and historically constructed concept, of which we learn through interactions with; family, peers, social institutions, the media, and such other connections that we make in our everyday lives. According to Peter Weinreich, one's identity is,

"Defined as the totality of one's self-construal, in which how one construes oneself is,

in the present, expresses the continuity between how one construes oneself as one was

and how one construes oneself as one aspires to be in the future. (Weinreich, Peter, and Wendy Saunderson. Analysing Identity: Cross-cultural, Societal, and Clinical Contexts. London: Routledge, 2003)

In light of this definition, it may be understood that the manner in which one sees him in the past, the present, and in the future, is what constitutes his identity. This understanding of oneself is, however, greatly by the perception of others around that person. The 'self' is located in a word defined by others. The power lies in the word - once the word changes, it changes with itself the identity of the person that it is associated with.

\section{The issue of Black - American identity}

The case of the Black- Americans is rather peculiar one, as far as the issue of their quest for identity and the process of the creation of their identity is concerned. The 'Blacks' as they are generally referred to, are Americans of African descent, who have been part of a very long history of slavery, that is, the legal enslavement of humans, primarily of Africans and African - Americans, that existed in the United States of America, in the $18^{\text {th }}$ and $19^{\text {th }}$ centuries, after it gained independence and before the end of the American Civil War. Up until the abolition of slavery on $18^{\text {th }}$ December 1865 , by President Abraham Lincoln, these 'Blacks' and 'Coloured' people were no less than chattel, or personal property, of their owners; treated worse than animals, they were used and abused at will - completely at the disposal of the whims and fancies of their so- called 'superior' White masters. Such was the extent of their subjugation and commodification that they completely lost all consciousness of their being actual living, breathing humans.

Even when slavery had been abolished, it had very little positive impact on the existence and issue of identity of this population and its people. The question, 'who am I?' continued to plague them, all through their lives and even bore down heavily on the lives of their succeeding generations. More often than not, they are more likely to see themselves, and to be 
seen by others as 'freed slaves', rather than free entities, in control of their lives and destinies. An example to this effect may be seen in an incident recorded in the memoir of an abolitionist, who upon having asked a slave about his self, got the answer, I ain't got no self. This single statement speaks volumes about the predicament, not of a lone individual, but that of an entire community, plagued by a history of brutality and subjugation, torn apart between 'who they were' and who they wanted to be.

It is this quest for identity on the part of the African -Americans and their arduous journey in the process of creating an identity for themselves, that the body of African- American literature, specially the novels of Toni Morrison, seeks to deal with, hoping to provide a keen insight, if not the solution into the heart- rending tales of suffering and death, and confusion, that their lives have been fraught with.

The role of the family is of paramount importance, when it comes the creation of the identity of an individual. The family is like a support system that provides much emotional and psychological succour to a person in all stages of life, especially, in the growing - up years of one's life, for want of which, the person is met with failure in the process of the achievement of identity. For lack of familial ties of love, and bonding, and mutual support, an individual becomes more susceptible to falling victim to inability in resolving the conflicts that arise in the Identity versus Role Confusion stage, as well as, in the Intimacy versus Isolation stage . It is this issue, or rather a stumbling block, in the process of the achievement of identity, that Morrison has explored in the novel, Beloved. The characters under consideration, Sethe and Paul D, both have led isolated existences, in that they have either had no known family, or they have been torn apart from them. The pain that is associated with such forced severance of ties is unbearable and irrevocable, and more often than not, it is the coming to terms with this pain, that will allow them to achieve an identity of their own. However, again, the problem that raises its ugly head is the issue of the suppression of memories, specially in the case of Paul D, leading to further complication in the process of the resolution of conflicts - as may well be gleaned from the analyses of the characters of both, Sethe and Paul D.

\section{SETHE}

As far as she could remember she did not have any relationship with her father or mother. Her mother was always burdened and overworked and exhausted that she had nothing left and her to give to her daughter, as part of herself even something as basic as nursing by her mother was a privilege that Sethe could never have. By the time Sethe work woke up and the morning her mother was already standing and aligned with others slave women. She never noticed her for more than two or three weeks she never comb the hair or dress her up -in short she was never given a chance to do any of the things that mother usually do for their daughters. All that she could do was to take Sethe aside and show her a mark of identification, so that when the time comes, the child would be able to tell her mother apart from the host of others live women who would be meeting similar ends. The time did come, and with the death of a mother, came the end of the first half of life of Sethe-allies with no memorable attachments, consequently failing to register itself and her mind.

Sethe, like all other adolescence, faced conflict of identity in various phases of his life. The problem however, lies in the fact that she is grossly and equipped on all friends to resolve these conflicts. In addition to her parents she has always been deprived of the company of her husband her children and also her mother and law. While Halle could stand within hours of need, in that he was present in the bar when Sethe was being violated by Schoolteacher's nephew and yet, he could not master the courage to intervene on her but, and when Sethe discovered this she gave him up for dead:

And as far as he is concerned, the world may as well know it. And if he was that broken then, he is also and certainly that now (Morrison, 2005:83).

Her children-Howard, Buglar and Beloved- all taken from her one or the other way. While the boys ran away owing to the ghost living and 124, she herself beloved, in a desperate bid to save her daughter from being reclaimed by school teacher. The only child left what is Denver, who she clings on to, for dear life, whom she is aggressively and fiercely protective of; something seen by Paul D and the others live as a grievous mistake on her part: For used to be slave women to love anything that much was dangerous specially if it was her child she had settled on to love (Morrison, 2005:109).

It was only with the coming of beloved that the earlier chapter of cities life cloaked in pain and humiliation slowly being to unfold true memories and flashbacks, and the reader is made aware of the anguish that she has endured and the toll that has taken on her, particularly, as well as psychologically and emotionally. It has left her a fractured individual with no sense of 'Self' as being a unique and distinct personality. First, it was the incident and the barn of Sweet Home where are milk was forcefully taken from her by the two nephews of school teacher, taking a perverted pleasure and physical and mental trauma. It was the incident, followed by the thrashing that made her decide that she could not take it anymore and that she had to escape from the hell created by school teacher and give her best shot at being united with the children. She undertook a backbreaking journey to reach Cincinnati even when she was heavily pregnant with Denver, home she delivered in the most inhospitable of conditions. It was so that she was successful in being united with the family. But while she was still revealing and the festivity of the stolen freedom, it was taken away from her. Soon, school Teacher Company by a number of his accomplices came to reclaim her at the children. No sooner did she see the man with that look coming towards 124 that she was overcome with the single thought to protect children from no matter what the extreme said that she had to restore to. Siri acted in a much unexpected manner. It urges the reader to question the source of the motivation that drove her to take such an extreme step-was it love? Was it insanity? Motherly instinct? The answer is provided by Sethe herself;

Because, the truth was simple ... when she saw them coming and recognised school teachers hat.....And if she thought anything, it was No, No, Nonono. Simple. She just flew collected every bit of life that she had made all the parts of her that was precious and fine and beautiful and carried and post dragged them... Where no one could hurt them...(Morrison, 2005:192). 
The return of Beloved from.com is like a way for fresher and her dead life. It fails with hope and optimism, for a better life a life of togetherness and bonding. She has resuscitated and rejuvenate it, and it would not be an appropriate in this situation that she has ever resolved minor fraction of the conflict in her identity:I lasted. And my girl came home. Now I can look at the things again... After the shed I had stopped. Now... I main to look out the window to see what the son is doing to the day (Morrison, 2005:237).

The sense of fulfilment and completeness is however, short-lived as beloved's presents and the house soon began to take a toll on the mental and physical health of city so that the time that will love it leaves them for good, she has completely lost touch with reality and has proven herself in seen so much so that when she so much as catches a glimpse of Mr. Bodwin's wide-rimmed black hat, she flies at him with ice pick and hand for few that he had come to reclaim her daughter and she had to keep him from being able to do so.

The yoke of slavery and the brutality of the white men had broken city beyond repair. That she was a sturdy and resilient women, only served to her disadvantage. Open, she was to lose her mind, to forget everything, to live in oblivion of a past- the next best alternative to dying, Sunset was not buying and giving up that was difficult, rather it was the living and holding on that was difficult. Each instant running away of Howard and Buglar, the death of Beloved return from death, the death of a mother in law the cause of which she was never able to admit even to herself, the revelation about Halle, the violation of her mother had pushed her father and further towards the precipice until she could hold on longer to its jagged point edge and fell into the Deep and bottomless abyss. And emotional mental and psychological wreck-it would not be misplaced to say that, in a quest for freedom and family she lost her self. She was never able to achieve an identity, since conflict remained unresolved, even until the very end. She could not attain that unique self had and was a field here at self construal-in the past, the present, and the future.

\section{PAUL D}

The major male character in Beloved, Paul D, is one of the Sweet Home men, along with Halle, Sixo and a number of Pauls, he being one among them. While Sethe had been brought into the Home, at the age of thirteen, when she had very little knowledge of life before it; he had been a slave on quite a number of farms before. He has seen a great deal of the world , and while Sethe's sufferings are subjective and personalized, those that Paul D has endured, are of a representative of the larger picture - the life of a slave , in general, not that it lessens his pain or sense of loss any more . He is the embodiment of the unstable, insecure, emotionally stunted and rootless existence of a fugitive ex-slave - all of these being symptomatic with a crisis of identity. He has endured incomprehensible pain and anguish, and as a result, he has shut his mind and his heart to any iota of emotions, feelings and sentiments - anything that would make him attached to a place or a person, and hence render him emotionally vulnerable. ... he had shut down a generous portion of his head, operating on the part that helped him walk, eat, sleep, sing ... he asked for no more (Morrison , 2005:49).

Since any more than that required him to dwell on the faces of actual people, his relations with them, the severance of ties from them, and so forth, and he could no longer bear any of it. It only gave him a raw, throbbing pain, which he did not know how to deal with. He heart has been rusted shut so that nothing affects him on a personal level.

Like almost every others, he has been subjected to in human treatment and answer for cables brutality. In the plantation at George he was simply one of the hands along with 45 others slave, not even following in the criteria so as to be considered human and being treated worse then animal. While he was still in Sweet Home after the death of Mr Graner he has been witnessed to Halle buckling up under the weight of self-loathing for the inability to save Sethe the humility of violation, Sixo being burnt alive, and he himself to live with the 'iron bit' NS mouth, usually put and the mouth of horse so as to rein them in, and an iron necklace around his neck. After having been sold by Schoolteacher, to a man called Brandywine, who he tries to kill, he found himself and worse living condition than even cattle. He has chained by the ankle to 45 other man and had to live in a box fitted into a rectangular hole in the ground. Every morning they were woken up by the sound of rifle shots come and fall in line with the apprehensively awaited there for the day. Expected to behave no less than machine, they were prone to frequent lashing and vaping, in keeping with the whims of whoever was in charge of them. It was the emotional and mental agony, more than the physical abuse that have the repercussions on their psyche. No one could tell the ruling of his blood or the trembling of his arms and legs, but when he was show when into his box and the cage door was dropped at shutdown "his hands quite taking instruction...they travelled... Nothing could stop them or get their attention... The miracle of their obedience came with the hammer at dawn"( Morrison, 2005: 128).

For Paul D, after eighty six days in that place," Life was dead" finally, glass sign of vitality and hope, where quest do nothing the proof of this assumption; his trembling stopped all together- the only manifestation of the battle has been fighting against the oppression he was subjected to. All the slaves escaped, had decided upon a plan of action for the futureall, except Paul D. Having deliberated for days on end, he finally chose to move north. When he asked for directions, the suggestion give him was "follow the tree flowers". He followed the path illuminated by the springtime blossoms comma choosing one flower at a time. In the novel of Morrison, comma colours are an important symbol- this time for love for life, for death, for the wilderness of the mind, for perfection and purity as well as for rottenness and puerility. It is as if life of animal is a right of colours, bright as well as been. So when Paul D takes the path shown by the spring blossom, characterized by rich and vibrant colours, symbolising life and hope and is oblivious to them, it is evident that he is dead inside. The death of Mr Graner and taking over of estate by school teacher was the worst incident. The new master did not treat them like or consider them as man rather; they were potential and profitable economical resource by the exploitation of which we hope to brighten his future prospects. Upon meeting Sethe after such a long time, he feels the urge to settle down, and tell her secret 
about having been and prison for the murder of Beloved trembles out in the open and unable to bear his disillusionment whether he moves out of 124 .

It is only at the very end of the novel that is equal to make peace with his past and put all his demons to rest and get the courage to return to city or more time only to find her in Baby Suggs' bed "pondering over colours". That he has resolved the conflict in the process of achievement of his identity is evident from the words of Sethe: me and you, we got more yesterday than anybody. We need some kind of tomorrow.... You, your best thing, Sethe. You are (Morrison, 2005:124).

It is true that even do not completely, at least to some extent he has opened up the 'tobacco tin' that he had been screwed shut, related to that some amount of the colour that nature has to care and some measure of sunshine in the darkness that had characterized it. The target however is that the conflict that ought to have been resolved value was still and adolescence find resolution when the better part of his life has been spent scourging for food and survival. Is quest for identityhome, security and stability- consumes has entire being only because skin colour and has ethnicity where to determine that he was chattel and rather than human of meticulous notes had to be taken so as to decide the corrective that should be affected upon him.

The process of creation of persons identity as a direct outcome of the manner in which he construes himself, which in turn influences the way he conducts himself with regards to others and ultimately determine the extent of acceptance the said person has come and the family as well as in the society. Sense once identity as constently in a state of flux it is influenced by various social and other forces that a person comes into contact with. Ever since a child is born, he is consciously and unconsciously aware of the opinions of other people old of him, and it is the manner in which day especially the member of the family reacts to his presence. Most often the an ability to solve an issue of Identity is of the lack of proper family support and guidance, however it has often been found that the society and the social mind set are also equally to be blamed. This can be seen in the novel The Bluest Eye by Toni Morrison and which she has portrayed the plight of an individual Pocola Breedlove, who fell with them to such social forces. Only fault is that she is 'ugly'. And the fact that she comes from a dysfunctional family only adds fuel to the fire. In contrast to her is Claudia MacTeer,, who faces almost similar crisis of identity but she emerges with two years and is able to achieve a unique Identity. The novel through the metaphor of obsession of particular, with blue eyes has sought to address the greater and more pressing issue, as to the accepted and required standards of beauty and what exactly constitutes ' beautiful' in the eyes of society.

\section{Pecola Beedlove}

Pecola having black skin and Negroid features is something that has been endowed upon her my nature, something that she can do nothing to help, and yet the social mind set a such that it does not allow for any digression from the normal, notwithstanding the fact that digression maybe something that individual has no say in. The manner in which, Pocola is literally ostracized by her classmates and teachers and all people around her korma so disheartening for that little girl that this social rejection becomes a major stumbling block in the process of creation of an identity and a unique self had for her. It is as a result of these factors that Pocola is unable to resolve the conflicts that rises in the course of creating creation of her identity, both in the Identity diffusion stage as well as identity foreclosure stage comma and that she is neither able to determine anything regarding the purpose and goals of a life, nor is she is able to stand up to the issue that pose themselves before. Her mind is characterized by procrastination and disorganisation of thoughts; as a consequence unable to think and decide for her she accepts all the negativity the society ascribes to her without any resistance on her part.

Pecola, who is at a crucial juncture in her life, is totally at sea as to the manner in which she should handle the issue of adolescence. It is at this time that she is most in need of the support of a family of parents of friends of good stable relationship that can help her tight through and come in terms with yourself. Wind soon realises that the conflict in the character of Akola lies in the conception of a self as wanting as someone who does not measure up to what is considered as normal. She has faced rejection all her life if- if not overtly then covertly and even though she may not have been able to consciously put a finger on it subconsciously she is totally aware of this lack on her part. even as she was born cheapest rejection, although it was not like the rejection faced by the father,Cholly, who has been abandoned by his mother on the railroad tracks the rejection that she faces is much more subtle- from the moment that her mother gave birth to her she at accepted that her daughter was ugly. A right smart baby she was... But I knowed she was ugly. Head full of pretty hair, but Lord she was ugly (Morrison, 2016:124).

Unconsciously, Pauline includes a daughter as is evident in the incident involving Pecola and her father, which resulted in a pregnancy. When the Pauline probably and the stud she never accepted that her daughter was innocent and the victim. In said, she preferred to show her affection on the daughter of the people in whose house she worked as a maid. In the light of these two instances it would not be wrong to say that as far as the achievement of identity and a unique sense of self had are concerned the college has already lost the fight since neither has she the strength to stand for herself not as she have the support of a parents of friends. To add to the complications Pecola has already accepted these traditional norms pertaining to herself and found herself grossly inadequate. she has never given herself a chance to decide which value and benefits are agreeable to her and which are not.so deeply ingrained in her cycle as the tendency of self loathing that not only is she drawn towards girls like Maureen Pale, who are considered to be the epitome of beauty she is inevitably found desperately wishing and even playing either for Blue eyes or that she should disappear from the face of the earth. So mesmerized is she were the thought of Blue eyes that anything that ever jumps to her notice is "the eyes of the people" (Morrison, 2016:45). Every night she frequently prays for Blue eyes: "Please, God," she whispered into the palms of her hand, "please make me disappear" (Morrison, 2016:43). 
It had occurred to Pocola some time ago that...if those eyes of us at different, that is to say beautiful, she herself would be different... If she looked different, beautiful maybe, Cholly would be different and Mrs Breedlove too. Her father, Cholly's contempt of the self began when he himself was a young boy, just coming to terms with himself, his sexuality, his personhood, his surroundings in short things that influence the process of creation of person's identity. His first sexual encounter ended in disaster- with white boys putting and hurdling abuse at him. And yet the anger that weld from deep inside the pit of his stomach was not against his perpetrator- the white boys- instead it was Derlene, the girl who was with him whom he hated for being there, and being the cause of his humiliation. It was on that fateful night that the confidence of a vivacious adolescence full of zest for life, abundant on the railway track as a four year old infant was crushed forever. The flashlight warmed its way into his gets and turned the sweet taste of muscadine into rotten fetid bile.

It cannot be constructed as anything short of provision on the part of the father but it is also essential to note that element of pathetic in his character, the impoverished state of his mind being such that he could not even find an himself any sanctity that is associated with the relationship that exists between a man and his daughter. The case of Pauline, Pocola's mother, is slightly different in that from other trajectory of the downward movement took a slightly different route. As a result of slide deformity on her foot going to negligence on the part of a parent she is deprived of a nickname funny and light headed remembrance of a happy childhood, o for that matter any of the tribal things that add up a huge until and contribute constructively to the creation of a person's identity. She became very mechanical and the way she goes about her day to day life, with the sole source of recreation being arranging things and ordering them up and need little rows. Having been neglected by a family and everyone else, all she was left to do by herself was fantasize about idyllic setting and romantic encounter with strangers who suddenly appeared out of nowhere and caressed her, understand her, and most importantly made her feel wanted- it was like some kind of cosmic conspiracy that caused her to meet Cholly Breedlove in the exact same way.

\section{Claudia MacTeer}

Claudia MacTeer is also an adolescent girl, almost the same age as Pecola , although a couple of years younger , who has spent a considerable amount of time in the company of the latter. She is the narrator and also the mouthpiece of Morrison in the novel. It is through the keen insight and penetrating vision of Claudia, that the reader sees the life of Pecola Breedlove unfolding. It is the element of the subjective and the poignant that makes the character realistic and life-like. Although it would not be wrong to say that both Claudia and her sister, Freida were friendly with Pecola, there is very little similarity that can pointed out between them. For instance the Macteer family is a close knit one , the bond between siblings is very strong, and the parents provide a comparatively better environment hat is more conducive to the resolution of the conflicts of identity that the girls will inevitably be faced with, in their growing-up years. The greatest factor that may be attributed to the advantage of Claudia is that, she put up a good fight against the forces that were rallying against her in order to weaken her resolve and defeat her spirit, so that she may be unsuccessful in achieving a unique and distinct identity for herself. In other words, she did not succumb to the pressure to look beautiful in the way that society and social norms expect one to do , this pressure being in the form of disapproving glances from people, the faces that stared back at you from billboards and even the dolls one received as gifts for Christmas. In terms of Pecola, one may say that she did not hanker after blue eyes - that is, an identity that was not meant for her.

A Black girl herself, from the very beginning, she had a strong dislike, a contempt, even a hatred for "all the Shirley Temples of the world. From the time that she was a little child, even though she did not realise as much, she began to dislike the dolls she received as presents on the occasion of Christmas. What irked her most was the similarity between all these dolls with their huge blue eyes. The "round moronic eyes, the pancake face, and orange worms hair" ( Morrison, 2016:10), filled her with fear and revulsion to such an extent that she had a deep desire to dismember all of them :To see what of it was made, to discover the dearness, to find the beauty, the desirability that had escaped me, but apparently only me .

This revulsion later manifested itself through jealousy and hatred of Maureen Peal - the epitome and embodiment of all that contained in itself the essence of being White, such that, "Black boys did not trip her in the halls; white boys didn't stone her, white girls didn't suck their teeth when she was assigned to be their work partner; black girls stepped aside when she wanted to use the sink ... and their eyes genuflected under sliding lids" (Morrison, 2016:60). And it is this revulsion that made her realise that when everyone in the school, including the Black children picked upon Pecola, "It was their contempt for their own blackness that gave the first insult its teeth" (Morrison, 2016:63). Comparing themselves with, Maureen Peal, both the sisters found themselves inadequate and even incompetent, and when they got into a tiff with her, the haughty retort of Maureen, "I am cute! And you ugly! Black and ugly black e mos. I am cute!" (Morrison, 2016.71), sets a storm in the mind of Claudia, and the questions that plague her mind are not of her but of the endless number of Claudias and Pecola.

If she was cute ... then we were not. And what did that mean? We were lesser... Dolls we could destroy, but we could not destroy the honey voices of our parents and aunts, the obedience in the eyes of our peers, the slippery light in the eyes of our teachers when they encountered the Maureen Peals of the world ... What did we lack ? (Morrison, 2016:72). Since the novel ends on a tragic note of Pecola's madness, one can only guess as to whether Claudia did find any satisfactory answers to her questions or not, but, what is certain is that she did succeed in resolving the conflicts in the process of the creation of her identity, and successfully reached the fourth and last stage of Marcia's Identity statuses, that is Identity Achievement.

The main reason behind a successful journey is that unlike Pecola, Claudia found the strength to stand up for herself. While everyone in school, including Pecola was lapping up every ounce of attention that Maureen Peal chose to bestow upon them, it was Claudia, accompanied by her elder sister, who had the courage to hold their own even when alone and deserted 
by all else. It is not as if she did not falter or stumble, but the difference between her predicament and that of Pecola was the presence of a loving family that protected her from all that was untoward, even though there were times that her mother became unreasonable in her obstinacy to protect her daughters from all that was not becoming to them. The fact that she hated these "Raggedy Anne dolls", with such fervour is rooted in her the fact that these dolls, rather than her, a living, breathing soul, were the objects of affection. It brings to light the fact that, very much like Pecola, Claudia, too sought love and acceptance, as is only natural.

\section{Conclusion}

The issue of identity of the Black Americans is a rather complicated one, in that ever since their forefathers were brought in to America as Negro slaves, to work on the plantations in the southern regions of America, they have been looked upon as slaves, with no independent sense of identity, no protesting voice and no representing face. It was only when there began to come into existence the various Slave narratives that this marginalised community began to emerge from the shadows of oblivion. The common issue addressed in almost all of these Slave narratives was the inability of the ex-slaves, and their successive generations, to come to terms with their identity, it is what Anthony Appiah refers to as, "the lack of a positive black identity." It is inevitable that a people who have been denied the right to literacy and language, should fail to carve a Self, for their person. Such is the uprooted nature of their existence that they do not know their own standing, either in society, or in their own esteem. They have been unable to shake off the psychological yoke of slavery that they, or their ancestors, have been under .They have been unable to come out of the shadow of humiliation, they have had to suffer at the hands of the very people with whom the Constitution has now given them a status of equality, the very same people of whom, it has been observed by Allan Johnston that, the laws and customs were such as confined the status and identity of the African-Americans to no more than chattel, never as humans, but as things. Since Blacks were considered to be inferior, they were forbidden from mingling with the Whites .It is as a result of this that, even after the abolition of slavery things did not change much in favour of them. The political condition was changed through a signature on the dotted line, a Bill passed in the Parliament, but this did not ensure any change either in the mind-set or the interactions that existed between individuals of both the communities.

\section{References:}

1. Weinreich, P. "The Operationalization of Identity Theory in Racial and Ethnic Relations". InRex,.j., \& Mason, D.(eds.) Theories of Race and Ethnic Relation. Cambridge: Cambridge University Press, 1986 .

2. Marcia, James. Identity Development - Aspects of Identity, Child Development Reference - Vol.4

3. Morrison, Toni. Beloved.Vintage publications, London, 2005

4. Morrison, Toni. The Bluest Eye. Vintage publications, London, 2016

5. Padmore Agbemabiese Is there a 'black key' to the white house ?Exploring African American identity portraits through the pen of African Americans, https://www.academia.edu/11913078/.

6. Nadya Kaddoura Ketty and M.Sarouphim, Identity development among Lebanese youth: An investigation of Marcia's paradigm. Heliyon, Volume 5, Issue 11, November 2019, e02851

7. Erik H. Erikson, Identity and the life cycle. WW Norton \& company, London, 1980.

8. Mohammed, Mahameed. "The Impact of Slavery in Toni Morrison's Beloved: From the Communal to the Individual." International Journal of Applied Linguistics and English Literature 7 (2018): 48-51.

9. Trotter, J. “The African American Experience.” Cengage Learning; 1st edition (December 11, 2000).

10. Kho and Younghee. "The Reclamation of Body in Beloved". The New Korean Journal of English Lnaguage \& Literature 58 (2016): 135-151. 